\title{
Plant growth promoting rhizobacteria (PGPR) as eco- friendly alternatives for management root-knot nematodes, Meloidogyne spp. on tomato plants.
}

\author{
El-Shawadfy M. Mousa ${ }^{1}$, Magdy, E. Mahdy ${ }^{2}$, Hanaa A. Abo- Koura ${ }^{3}$, Hasnaa F, F, El- \\ nagar $^{4}$
}

${ }^{1,2,4}$ Agric. Botany Dept., Fac. of Agric.; Menoufia University; Shebin El-Kom; Egypt

${ }^{3}$ Department Agricultural Microbiological Research, Soils, Water and Environment Research Institute (SWERI), Agricultural Research Center (ARC), Giza, Egypt.

\begin{abstract}
Plant Growth Promoting rhizobacteria (PGPR) are a various group of bacteria that could be create in the rhizosphere, at root surfaces and in association with roots. PGPR can be used as bio-control agents. The objective of this study was to assess four different bacterial strains i.e. Pseudomonas fluorescens, Azospirillum brasilense, Azotobacter chroococcum and Bacillus megaterium against Meloidogyne spp at three different incubation times i.e. 24, 48, 72 and $168 \mathrm{hrs}$ under laboratory conditions. Furthermore, the strains were evaluated at different application times i.e. (one week before, at the same time and one week after nematode inoculation) as bio- control agents against Meloidogyne spp. on tomato plants in pots experiments. In vitro results revealed that the highest inhibition percentage in egg hatching and larvae mortality recorded after $168 \mathrm{hrs}$ with B. megaterium by $17.3 \%$ and $92 \%$, respectively. Greenhouse, results cleared that all evaluated bacterial strains at all different application times had the potentiality in Meloidogyne spp. parameters reduction i.e. (number of galls, egg masses, females/root system and juveniles in soil) and the reproduction to a huge extent compared to treated plants with nematode alone. Plants inoculated with $B$. megaterium achieved also the highest increases in shoot and
\end{abstract}


root lengths and weights when applied one week before nematode inoculation by $213.3,175,180 \& 291.3 \%$, respectively compared to the other application times. Also it the highest values of ch.a, chl.b, total chlorophyll and carotenoids by 1.0, $0.75,1.75$ and $0.78 \mathrm{mg} /$ g.f.w., respectively recorded with B.megaterium when applied one week before nematode inoculation after 30 days from transplanting. Plants inoculated with A. chroococcum recorded the lowest photosynthetic pigments. Peroxidase (POX) and polyphenol oxidase (PPO) were increased with all bacterial strains treatments. The significant increase of dehydrogenase activity and total count of bacteria of all different bacterial strains observed when applied at all three application times were compared to plants infected with nematode alone.

Keywords: Meloidogyne spp., PGPR, Tomato (Solanum lycopersicum) , Photosynthetic pigments, Antioxidant enzymes.

\section{INTRODUCTION}

Root-knot nematodes (RKN) are the most essential nematode pests worldwide due to their great damage resulted on the very wide host range which contains more than 2000 plant species (Gugino et al., 2008). Rootknot nematodes Meloidogyne spp. are common in Egypt and worldwide and cause severe crop harmful especially in light soils (Abd-Elgawad and Aboul-Eid , (2001). The achievement of nematode reproduction on their appropriate hosts depends on the successful formation of such feeding sites which rely on the availability of appropriate concentrations of some chemicals and enzymes (BaldacciCresp et al., 2012) to be available in host tissues. PGPR is a diverse group of free-living soil bacteria that colonize rhizosphere and contribute to plant growth promotion which in turn increase the yield of agriculture 
crops Siddiqui and Shaukat (2002). PGPR plays significant role in the growth of sustainable agriculture system and is one of the main components in integrated nematode management (Teymouri et al., 2016). Egg-parasitic fungi, nematode trapping fungi, bacteria, and polyphagous predatory nematodes are biological control agents that have been evaluated ( Kerry \& Hidalgo-Diaz, 2004; Kiewnick and Sikora, 2005; Abdelmoneim, 2006). PGPR have exposed positive effects on tomato fruit quality, mainly on size and texture (Hortencia et al., 2007). Plant growth promoting substances from PGPR strains directly stimulus their host plant growth by inducing the cell division, tissue improvement, physiological and biochemical metabolisms. Though, these PGPR strains provide other maintenance to the host plant to cope up with nematode infection (Mhatre et al., 2019). The present study was approved out to evaluate the effect four bacterial strains i.e. P. fluorescens, A. brasilense, $A$. chroococcum and $B$. megaterium on tomato plants performance infected with root knot nematodes Meloidogyne spp. under greenhouse conditions at three different application times (one week before, at the same time and one week after nematode infection).

\section{MATERIALS AND METHODS}

\section{Microbial Inoculants}

Bacterial strains included P. fluorescens, A. brasilense, A. chroococcum and B. megaterium were obtained from the Department of Agricultural Microbiological Research, Soils, Water and Environment Research Institute (SWERI), Agricultural Research Center (ARC), Giza, Egypt. For inoculum preparation, a loop of each bacterium kindly was transferred into nutrient broth (NB) according to Difco Manual (1985) and was incubated for $24 \mathrm{hr}$ at $28^{\circ} \mathrm{C}$, and cell pellets were collected by centrifuging at $6000 \mathrm{rpm}$ for 10 minutes after the cells were washed in sterile distilled 
water and re-suspended in $400 \mathrm{ml}$ phosphate buffer $\mathrm{pH} 7$. After $24 \mathrm{~h}$, the turbidity of each bacterial culture was measured at wave length $600 \mathrm{~nm}$ and adjusted to $0.5 \mathrm{OD}\left(10^{7} \mathrm{cfu} / \mathrm{ml}\right)$.

\section{Preparation of Meloidogyne spp. inoculum}

Root-knot nematodes Meloidogyne spp. was multiplied on tomato plants (Lycopersicon esculentum Mill. Cv. GS) which was transplanted in plastic pots with diameter $30 \mathrm{~cm}$ filled with non-sterilized sandy soil under greenhouse conditions at the experimental farm, Faculty of Agric., Menoufia Univ., Shebin El-Kom. Four months after, the infested roots by Meloidogyne spp., were used to prepare nematode inoculum as described by Hussey and Barker (1973).

Egg masses of Meloidogyne spp. were stained by the protocol described by (Daykin and Hussey, 1985), while gall index measuring was determined according to the scale (0-10) of (Bridge and Page, 1981).

\section{In vitro experiment :}

\section{Egg hatching and Larvae mortality of Meloidogyne spp .}

The hatched eggs percentage was enumerated as follows:

Hatched eggs percentage $=$ Number of hatched eggs in each treatment/ Total number of eggs $\times 100$.

The mortality percentage of larvae was enumerated as follows:

Larvae mortality percentage $=$ Number of dead larvae in each treatment $/$ Total number of larvae x 100

\section{Greenhouse Experiments:}

Tomato seeds (Lycopersicon esculentum Mill cv. GS) were obtained from a commercial nursery to perform the experiment. The seedlings were transplanted in black bags of polyethylene at the rate of (one seedling /pot) filled with $2 \mathrm{~kg}$ sandy-loamy soil mixture at the rate of $(2: 1 ; \mathrm{v} / \mathrm{v})$. The experiment was designed as a complete randomized blocks with 
three replicates. Plants were daily watered and fertilized weekly with 5 $\mathrm{ml}$ of $2 \mathrm{~g} / \mathrm{L}$ of $\mathrm{N}: \mathrm{P}: \mathrm{K}$ (20:20:20) as recommended dose for Egyptian Ministry of Agriculture's. Eight weeks after nematode inoculation, plants were uprooted and their roots gently washed under tap water. The nematode inoculum was added at the same time of transplanting at the rate of 3000 eggs/plant in all pots except 3 pots served as a control. The eggs were inoculated in three holes around the root zone by pipetting. Fourteen treatments were carried out by applying each bacterium of all four bacterial strains at three different times with 6 pots served as a positive and negative control.

Plant biometrics was estimated at 30 and 60 days from transplanting, this included measurement of growth characteristics i.e. shoot and root length $(\mathrm{cm})$, root and shoot fresh weights $(\mathrm{g})$ as well as shoot dry weight (g).

\section{Photosynthetic pigments determination}

Total chlorophyll amounts, chlorophyll a, chlorophyll b and carotenoids pigments were determined in the leaves of plants by the method of Arnon (1949).

\section{Antioxidant Enzymes}

Peroxidase (POX) and polyphenol oxidase (PPO) enzymes activity was determined according to (Chance and Maehly, 1955) and Brooche (1954) after 30 days from transplanting.

\section{Dehydrogenase activity and total viable aerobic bacteria in rhizosphere soil:}

Dehydrogenase activity in the soil was carried out according to Thalman (1967) while the total viable aerobic bacteria were determined according to the method described by Vincent (1970). 


\section{Statistical Analyses}

Least significant difference test was used to compare means using the statistical analysis software; CoStat (CoHort Software, U.S.A) version 6.4, as described by Duncan (1955).

\section{RESULTS}

\section{$\underline{\text { In vitro Experiments }}$}

Impact of four different bacterial strains on egg hatching of Meloidogyne spp.

The inhibition percentage of egg hatching of Meloidogyne spp. studied under laboratory conditions at $28^{\circ} \mathrm{C}$ by using four liquid bacterial strains i.e. P. fluorescens, A. brasilense, A chroococcum and B. megaterium at different incubation times i.e. 24, 48, 72 and 168 hrs. Results revealed that all treatments exhibited nematicidal effects against egg hatching compared to control. B. megaterium recorded the highest inhibition percentage at all different incubation times, followed by P.fluorescens, A. brasilense and A.chroococcum, respectively compared to control. The highest inhibition percentage of egg hatching achieved after $168 \mathrm{hrs}$ in all treatments. The lowest values recorded after $168 \mathrm{hrs}$ by 17.3, 34, 42 and $50 \%$, respectively compared to control as recorded $87.3 \%$ after $168 \mathrm{hrs}$ as shown in Figure (1). 


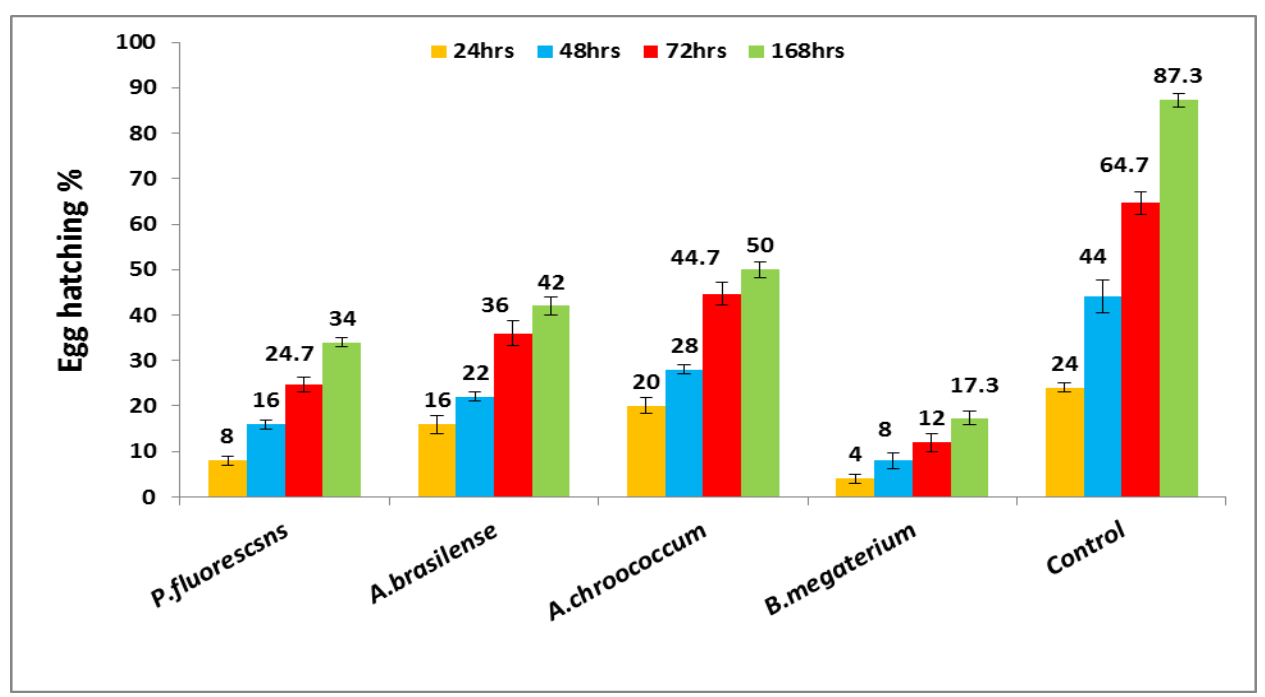

Figure (1): Egg hatching as affected by four bacterial strains at different times under laboratory conditions. Error bars represent the standard deviation between 3 replicates.

Impact of four different bacterial strains on juveniles mortality of Meloidogyne spp.

The juveniles mortality percentage of Meloidogyne spp. studied under laboratory conditions at $28^{\circ} \mathrm{C}$ by using the liquid of four bacterial strains i.e. P. fluorescens, A. brasilense, A. chroococcum and B. megaterium at different incubation times i.e. $24,48,72 \& 168$ hrs. Results revealed that all treatments exhibited nematicidal effects on juveniles mortality compared to control. B. megaterium gave the highest percentage of juveniles mortality at all intervals times, followed by P.fluorescens ; A.brasilense and A.chroococcum. The highest mortality percentage value recorded after $168 \mathrm{hrs}$ in all treatments. The highest mortality percentage of juveniles recorded $92 \%$ with B. megaterium after168 hrs, followed by P.fluorescens as recorded $80 \%$ and A. brasilense by $74 \%$, while $A$. chroococcum recorded $64 \%$ compared to control by $16 \%$ as shown in Figure (2) . 


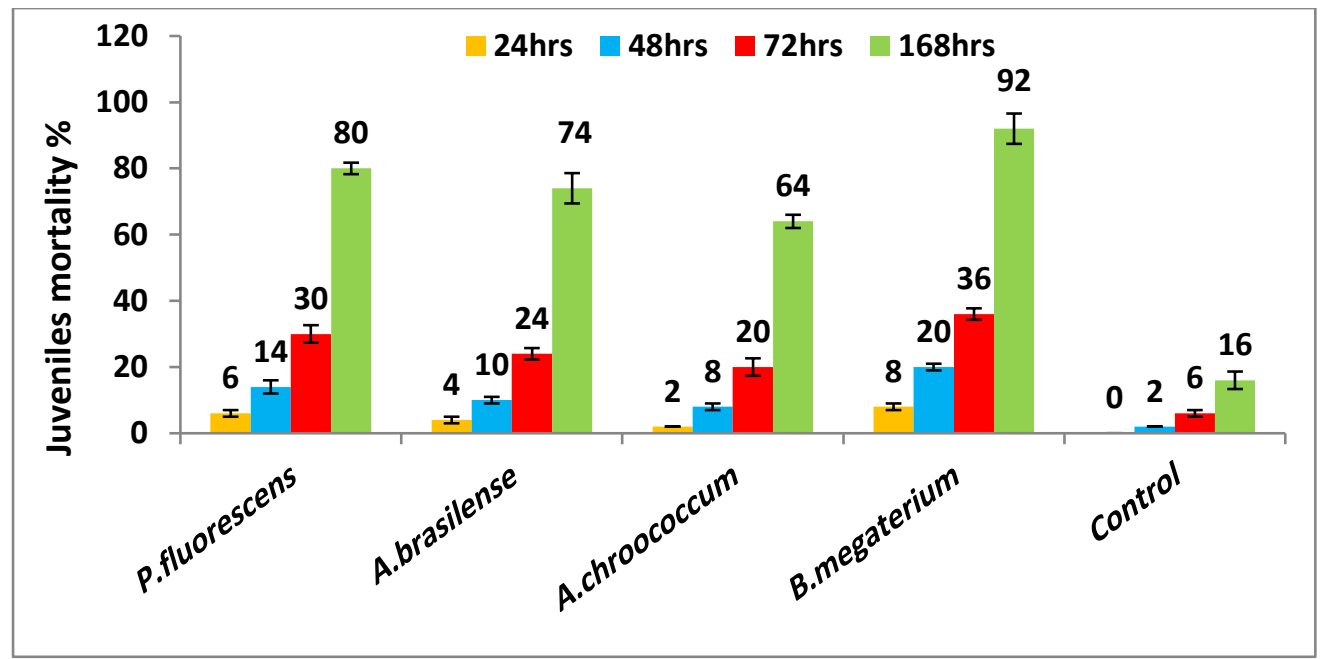

Figure (2): Juveniles mortality as affected by four bacterial strains at different incubation times under laboratory conditions. Error bars represent the standard deviation between 3 replicates .

\section{$\underline{\text { In vivo experiments }}$}

\section{Effect of four different bacterial strains at three applications times on} management of Meloidogyne spp.

To evaluate the effect of four bacterial strains viz ( $P$. fluorescens, $A$. brasilense, A. chroococcum \& B. megaterium) against root-knot nematodes Meloidogyne spp., a pot experiment was carried out under greenhouse conditions at three different application times (one week before, at the same time \&one week after nematode inoculation) as presented in Table (1). Generally, results cleared that all bacterial strains had the potentiality decrease in Meloidogyne spp. parameters i.e. (galls, egg masses, females/root system and $\mathbf{J}_{\mathbf{2}}$ in soil) and the reproduction as well as the final population to a huge extent compared to treated plants with nematode alone. The reduction percentage varied among treatments according to the species of bacterial strains and application times also. Application of four bacterial liquid strains at one week before nematode inoculation gave the highest reduction in nematode parameters in soil and 
roots. The reduction percentages in nematode parameters in soil and roots were ranged between 62 to $93.3 \%$, respectively. The highest reduction in numbers of galls, egg masses, females/root system and $\mathbf{J}_{2} / 250 \mathrm{~g}$ soil recorded with plants inoculated with $B$. megaterium at one week before nematode inoculation by $86,88,88.9 \& 93.3 \%$, respectively, followed by the same bacteria at the same time of nematode inoculation by 85, 90, $86.1 \& 92.5 \%$, respectively, while when the bacteria was inoculated one week after nematode inoculation the reduction was $84.2,86,83.9 \& 92 \%$ , respectively compared to plants treated with nematode alone. Inoculation plants with $P$. fluorescens decreased the number of galls, egg masses and females / root system and number of $\mathbf{J}_{2} / 250 \mathrm{~g}$ soil by $83.3,84,82.2 \& 91.6 \%$, respectively when it applied one week before nematode inoculation, followed by it applying at the same time of nematode inoculation by $82.6,82,80 \& 91.2 \%$, respectively compared to treated plants with nematode alone. Applying $P$. fluorescens one week after nematode inoculation recorded reduction percentages in galls, egg masses, and females / root system and $\mathbf{J}_{2} / 250 \mathrm{~g}$ soil by $82,79,77.8 \&$ $90.6 \%$, respectively compared to plants treated with nematode alone. Similarly, applying A. brasilense at one week before of nematode inoculation achieved high results in decreasing the number of galls, egg masses, females in root system and $\mathbf{J}_{2}$ in soil at the rate of $81.6,77,75.6$ \& $90.2 \%$ respectively, followed by applying this bacterium at the same time of nematode inoculation by $80,75,73.3 \& 89.7 \%$, respectively, then applying the bacterium one week after nematode inoculation by 79, 72, 71.7 , \& $89.3 \%$, respectively compared to plants treated with nematode alone. On the other hand, inoculated plants with A. chroococcum one week before nematode inoculation gave the least results in decreasing numbers of galls, egg masses, females / root system and number of $\mathbf{J}_{2}$ / 
$250 \mathrm{~g}$ soil by $78,69,70 \& 88.9 \%$ respectively, followed by applying at the same time of nematode inoculation by $77.4,65,68.9 \& 88.5 \%$, respectively, but when applied one week after nematode inoculation recorded 77, 62, 67.2, \& 88.1\%, respectively. Also, all treatments significantly decreased the final nematode population and this was reflected on reproduction factor. The least final nematode population obtained with $B$. megaterium when applied one week before

Table (1): Effect of four bacterial strains at three different application times on management of Meloidogyne spp. on tomato plants under greenhouse conditions

\begin{tabular}{|c|c|c|c|c|c|c|c|c|c|c|c|}
\hline $\begin{array}{l}\text { Bacterial } \\
\text { strains }\end{array}$ & $\begin{array}{l}\text { Applicatio } \\
\text { ns time }\end{array}$ & $\begin{array}{l}\text { Galls/ro } \\
\text { ot } \\
\text { system }\end{array}$ & 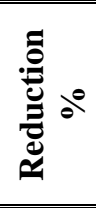 & $\begin{array}{l}\text { Egg } \\
\text { masse } \\
\text { s/root } \\
\text { syste } \\
\text { m }\end{array}$ & 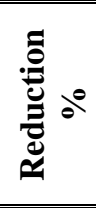 & $\begin{array}{l}\text { Femal } \\
\text { es/root } \\
\text { system }\end{array}$ & 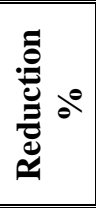 & $\begin{array}{l}\mathbf{J} 2 / 250 \\
\text { g soil }\end{array}$ & 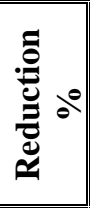 & PF & $\mathbf{R F}$ \\
\hline \multirow{3}{*}{ 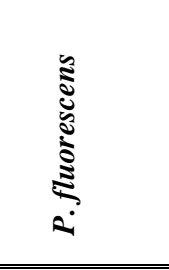 } & $\begin{array}{c}\text { One week } \\
\text { before }\end{array}$ & $83^{\mathrm{def}}$ & 83.4 & $16^{\text {fghi }}$ & 84 & 32.2 & 82.2 & $126^{\mathrm{hij}}$ & $\begin{array}{c}91 . \\
6\end{array}$ & 257 & 0.09 \\
\hline & $\begin{array}{c}\text { At the } \\
\text { same time }\end{array}$ & $87^{\mathrm{def}}$ & 82.6 & $\begin{array}{c}18 \\
\text { efghi }\end{array}$ & 82 & $36^{\text {fgh }}$ & 80 & $132^{\mathrm{ghi}}$ & $\begin{array}{c}91 . \\
2 \\
\end{array}$ & 273 & 0.09 \\
\hline & $\begin{array}{c}\text { One week } \\
\text { after }\end{array}$ & $90^{\text {cde }}$ & 82 & $21^{\text {defgh }}$ & 79 & 40 efg & 77.8 & $141^{\text {fgh }}$ & $\begin{array}{c}90 . \\
6\end{array}$ & 292 & 0.1 \\
\hline \multirow{3}{*}{ 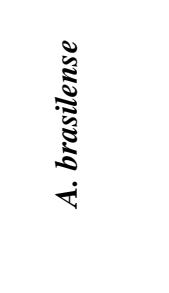 } & $\begin{array}{c}\text { One week } \\
\text { before }\end{array}$ & $92^{\text {cde }}$ & 81.6 & $23^{\mathrm{def}}$ & 77 & $44^{\mathrm{def}}$ & 75.6 & $147^{\text {efg }}$ & $\begin{array}{c}90 . \\
2\end{array}$ & 306 & 0.1 \\
\hline & $\begin{array}{c}\text { At the } \\
\text { same time } \\
\end{array}$ & $100^{\mathrm{bcd}}$ & 80 & $25^{\text {def }}$ & 75 & $48^{\text {cde }}$ & 73.3 & $154^{\mathrm{def}}$ & $\begin{array}{c}89 . \\
7 \\
\end{array}$ & 327 & 0.1 \\
\hline & $\begin{array}{c}\text { One week } \\
\text { after }\end{array}$ & $105^{\mathrm{bc}}$ & 79 & $28^{\text {cde }}$ & 72 & $51^{\text {bcd }}$ & 71.7 & $160^{\text {cde }}$ & $\begin{array}{c}89 . \\
3\end{array}$ & 344 & 0.1 \\
\hline \multirow{3}{*}{ 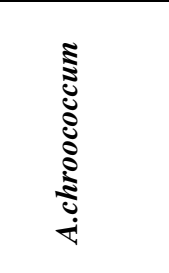 } & $\begin{array}{c}\text { One week } \\
\text { before }\end{array}$ & $110^{\mathrm{b}}$ & 78 & $31^{\mathrm{bcd}}$ & 69 & $54^{\mathrm{bc}}$ & 70 & $167^{\mathrm{bcd}}$ & $\begin{array}{c}88 . \\
9 \\
\end{array}$ & 362 & 0.1 \\
\hline & $\begin{array}{c}\text { At the } \\
\text { same time } \\
\end{array}$ & $113^{\mathrm{b}}$ & 77.4 & $35^{\mathrm{bc}}$ & 65 & $56^{\mathrm{bc}}$ & 68.9 & $172^{\mathrm{bc}}$ & $\begin{array}{c}88 . \\
5 \\
\end{array}$ & 376 & 0.1 \\
\hline & $\begin{array}{c}\text { One week } \\
\text { after }\end{array}$ & $115^{\mathrm{b}}$ & 77 & $38^{\mathrm{b}}$ & 62 & $59^{\mathrm{b}}$ & 67.2 & $179^{\mathrm{b}}$ & $\begin{array}{c}88 . \\
1\end{array}$ & 391 & 0.1 \\
\hline \multirow{3}{*}{ 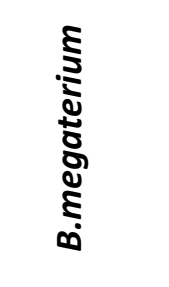 } & $\begin{array}{c}\text { One week } \\
\text { before }\end{array}$ & $70^{f}$ & 86 & $12^{\text {hi }}$ & 88 & $20^{j}$ & 88.9 & $100^{\mathrm{k}}$ & $\begin{array}{c}93 . \\
3 \\
\end{array}$ & 202 & 0.07 \\
\hline & $\begin{array}{c}\text { At the } \\
\text { same time }\end{array}$ & $75^{\mathrm{ef}}$ & 85 & $10^{\mathrm{i}}$ & 90 & $25^{\mathrm{ij}}$ & 86.1 & $112^{\mathrm{jk}}$ & $\begin{array}{c}92 . \\
5 \\
\end{array}$ & 222 & 0.07 \\
\hline & $\begin{array}{c}\text { One week } \\
\text { after }\end{array}$ & $79^{\mathrm{ef}}$ & 84.2 & $14^{\text {ghi }}$ & 86 & $29^{\mathrm{hi}}$ & 83.9 & $120^{\mathrm{ij}}$ & 92 & 242 & 0.08 \\
\hline $\begin{array}{l}\text { Nematode } \\
\text { alone }\end{array}$ & ----- & $500^{\mathrm{a}}$ & ---- & $100^{\mathrm{a}}$ & ----- & $180^{\mathrm{a}}$ & ---- & $1500^{\mathrm{a}}$ & ---- & $\begin{array}{c}228 \\
0\end{array}$ & 0.8 \\
\hline $\begin{array}{c}\text { LSD at } \\
0.05 \\
\end{array}$ & ---- & 12.1 & ----- & 7 & ----- & 7.2 & --- & 31 & --- & & \\
\hline
\end{tabular}




\section{Growth characteristics of tomato plants}

Data represented in Table (2) showed that all bacterial strains improved growth characters of nematode infected tomato plants compared to plants infected with nematode alone. The best performing conditions are those when bacteria were added one week before nematode inoculation .The treatment of B.megaterium achieved the highest increases in shoot and root lengths, shoot and root fresh weights when applied one week before nematode inoculation as recorded 213.3, 175, 180 \& 291.3\%, respectively. Inoculation tomato plants with $B$. megaterium at the same time of nematode inoculation also enhanced the growth parameters by $200,162.5,160 \& 269.6 \%$, respectively compared to plants treated with nematode alone. Inoculation tomato plants with B. megaterium one week after nematode inoculation recorded low increase percentages in shoot and root lengths as well as weights 193.3, 143.8, 155,175\&247.8\%, respectively compared to the other application times. Plants inoculated with $P$. fluorescens achieved increase percentages in growth parameters which occupies the second rank after B.megaterium, followed by $A$. brasilense and A.chroococcum. On the other hand plants inoculated with $P$. fluorescens one week before nematode inoculation augmented the growth parameters such as shoot and root lengths by 173.3 and $131.3 \%$, respectively as well as shoot and root fresh weights by 140 and $217.4 \%$, respectively, while the shoot dry weight by $162.5 \%$. The treatment of $A$. brasilense occupied the third rank after $P$. fluorescens in increasing the plant growth parameters. The highest percentage of increase in shoots and root lengths by 126.7 and $100 \%$, respectively. The minimum impact on growth criteria recorded by A. chroococcum compared to the other isolates. 
Table (2): Effect of four bacterial strains at three different applications times on

plant growth characteristics of tomato plants infected with Meloidogyne spp. under greenhouse conditions

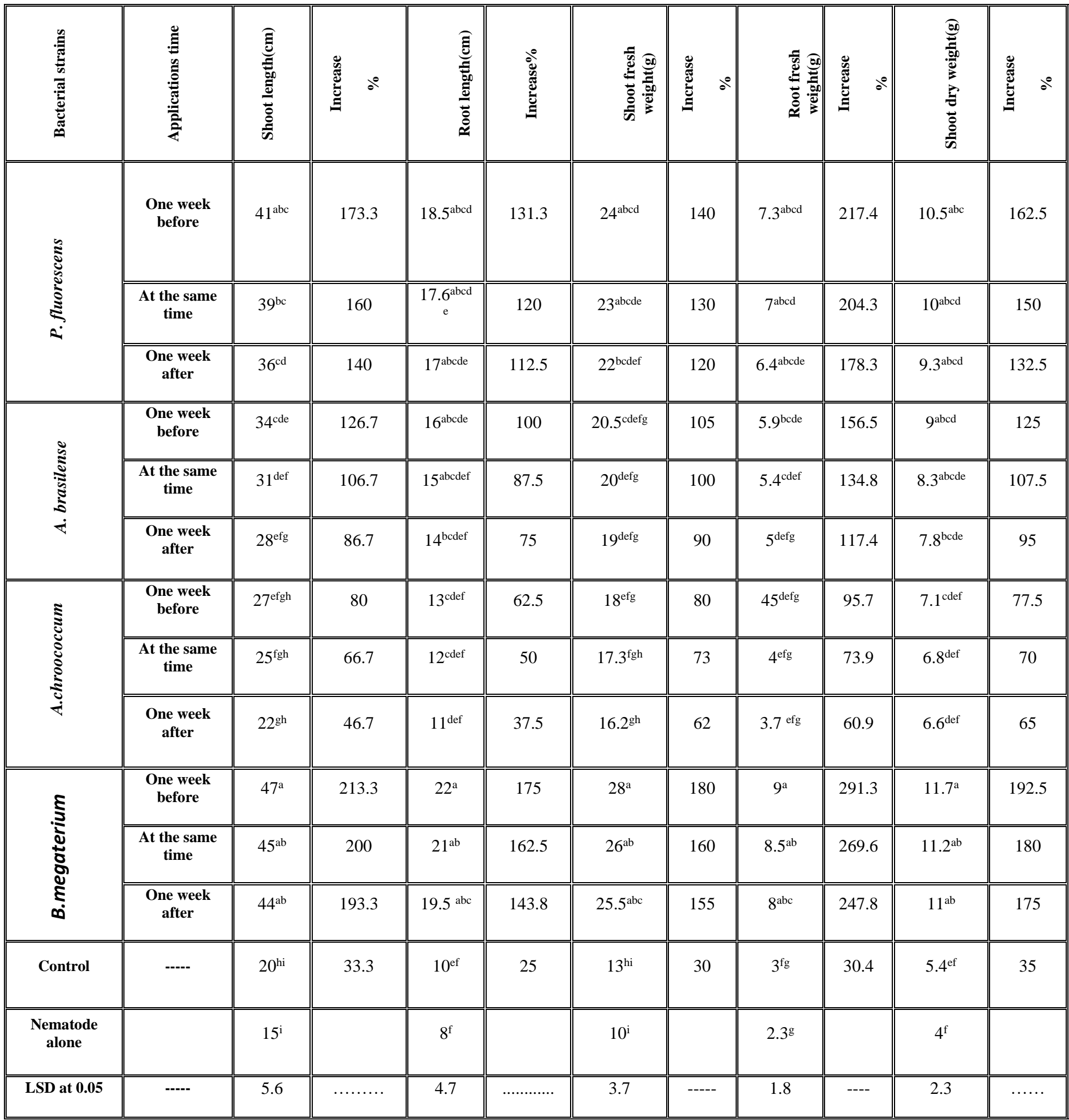




\section{Photosynthetic pigments in shoots of tomato plants}

Data illustrated in Table (3) proved that all bacterial strains significantly increased the activity of photosynthetic pigments in plants when applied at all three application time compared to treated plants with nematode alone. Inoculation tomato plants with bacterial strains one week before nematode inoculation fulfilled the highest increase in pigments concentration followed by applying them at the same time then at one week after nematode inoculation. Inoculation with $B$. megaterium gave highest ch.a, chl.b, total chlorophyll and carotenoids as recorded 1.0, $0.75,1.75$ and $0.78 \mathrm{mg} / \mathrm{g}$. f. w. , respectively at one week before nematode inoculation after 30 days from transplanting, while it recoded $2,1.5,3.5$ and $1.8 \mathrm{mg} /$ g.f.w. , respectively in ch.a, chl.b, total chlorophyll and carotenoids after 60 days from transplanting compared to control . Inoculation plants with $A$. chroococcum gave the lowest photosynthetic pigments compared to other strains when it used at one week after it recorded $0.81,0.60,1.41$ and 0.78 (mg/ g.f.w.) respectively, in ch.a, chl.b, total chlorophyll and carotenoids after 30 days from sowing while it recorded 1.61,1.27,2.88 and 1.56 (mg/ g.f.w.) respectively, in ch.a, chl.b, total chlorophyll and carotenoids after 60 days from transplanting. Generally, inoculation bacterial strains one week before nematode inoculation gave highest photosynthetic pigments, while when the inoculation was one week after it recorded lowest photosynthetic pigments. 
Table (3): Effect of four liquid bacterial strains at three different application times on photosynthetic pigments concentration of plants infected with

\begin{tabular}{|c|c|c|c|c|c|c|c|c|c|}
\hline \multirow{2}{*}{$\begin{array}{l}\text { Bacterial } \\
\text { strains }\end{array}$} & \multirow{2}{*}{$\begin{array}{l}\text { Applications } \\
\text { time }\end{array}$} & \multicolumn{2}{|c|}{\begin{tabular}{|l} 
Chl.a \\
(mg/g.f.w.)
\end{tabular}} & \multicolumn{2}{|c|}{ (mg/g .f.w.) } & \multicolumn{2}{|c|}{$\begin{array}{l}\text { Total Chlorophyll } \\
\text { (mg/g .f .w.) }\end{array}$} & \multicolumn{2}{|c|}{$\begin{array}{l}\text { Carotenoids } \\
\text { (mg/g.f .w.) }\end{array}$} \\
\hline & & $\begin{array}{l}30 \\
\text { days }\end{array}$ & 60 days & 30 days & 60 days & 30 days & 60 days & $\overline{30 \text { days }}$ & 60 days \\
\hline \multirow{3}{*}{ 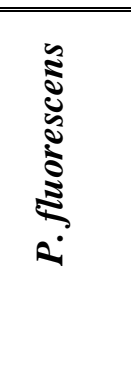 } & $\begin{array}{ll}\text { One } & \text { week } \\
\text { before } & \end{array}$ & $0.94^{\mathrm{a}}$ & $1.87^{\mathrm{a}}$ & $0.72^{\mathrm{a}}$ & $1.43^{\mathrm{a}}$ & $1.66^{\mathrm{a}}$ & $3.3^{\mathrm{a}}$ & $0.86^{\mathrm{a}}$ & $1.72^{\mathrm{a}}$ \\
\hline & $\begin{array}{l}\text { At the same } \\
\text { time }\end{array}$ & $0.92^{\mathrm{a}}$ & $1.84^{\mathrm{a}}$ & $0.71^{\mathrm{a}}$ & $1.41^{\mathrm{a}}$ & $1.63^{\mathrm{a}}$ & $3.25^{\mathrm{ab}}$ & $0.85^{\mathrm{a}}$ & $1.7^{\mathrm{a}}$ \\
\hline & $\begin{array}{l}\text { One week } \\
\text { after }\end{array}$ & $0.91^{\mathrm{a}}$ & $1.82^{\mathrm{a}}$ & $0.69^{\mathrm{ab}}$ & $1.38^{\mathrm{a}}$ & $1.6^{\mathrm{a}}$ & $3.2^{\mathrm{ab}}$ & $0.85^{\mathrm{a}}$ & $1.69^{\mathrm{a}}$ \\
\hline \multirow{3}{*}{ 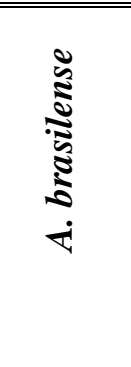 } & $\begin{array}{ll}\text { One week } & \text { before }\end{array}$ & $0.89^{\mathrm{a}}$ & $1.78^{\mathrm{a}}$ & $0.68^{\mathrm{ab}}$ & $1.36^{\mathrm{a}}$ & $1.57^{\mathrm{ab}}$ & $3.14^{\mathrm{ab}}$ & $0.84^{\mathrm{a}}$ & $1.67^{\mathrm{a}}$ \\
\hline & $\begin{array}{l}\text { At the same } \\
\text { time }\end{array}$ & $0.88^{\mathrm{a}}$ & $1.76^{\mathrm{a}}$ & $0.67^{\mathrm{ab}}$ & $1.34^{\mathrm{a}}$ & $1.55^{\mathrm{ab}}$ & $3.1^{\mathrm{ab}}$ & $0.83^{\mathrm{a}}$ & $1.65^{\mathrm{a}}$ \\
\hline & $\begin{array}{l}\text { One week } \\
\text { after }\end{array}$ & $0.87^{\mathrm{a}}$ & $1.73^{\mathrm{a}}$ & $0.66^{\mathrm{ab}}$ & $1.32^{\mathrm{a}}$ & $1.53^{\mathrm{ab}}$ & $3.05^{\mathrm{ab}}$ & $0.81^{\mathrm{a}}$ & $1.62^{\mathrm{a}}$ \\
\hline \multirow{3}{*}{ 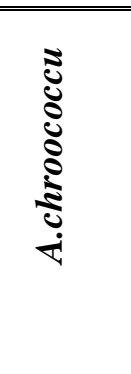 } & $\begin{array}{ll}\text { One } & \text { week } \\
\text { before } & \end{array}$ & $0.85^{\mathrm{a}}$ & $1.7^{\mathrm{a}}$ & $0.65^{\mathrm{abc}}$ & $1.3^{\mathrm{a}}$ & $1.5^{\mathrm{ab}}$ & $3.0^{\mathrm{ab}}$ & $0.8^{\mathrm{a}}$ & $1.6^{\mathrm{a}}$ \\
\hline & $\begin{array}{l}\text { At the same } \\
\text { time }\end{array}$ & $0.83^{\mathrm{a}}$ & $1.65^{\mathrm{a}}$ & $0.64^{\mathrm{abc}}$ & $1.29^{\mathrm{a}}$ & $1.47^{\mathrm{ab}}$ & $2.94^{\mathrm{ab}}$ & $0.79^{\mathrm{a}}$ & $1.58^{\mathrm{a}}$ \\
\hline & $\begin{array}{ll}\text { One week } \\
\text { after }\end{array}$ & $0.81^{\mathrm{a}}$ & $1.61^{\mathrm{a}}$ & $0.6^{\mathrm{abc}}$ & $1.27^{\mathrm{a}}$ & $1.41^{\mathrm{ab}}$ & $2.88^{\mathrm{ab}}$ & $0.78^{\mathrm{a}}$ & $1.56^{\mathrm{a}}$ \\
\hline \multirow{3}{*}{ 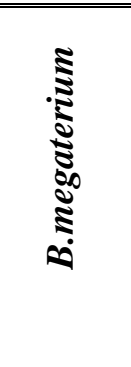 } & $\begin{array}{ll}\text { One week } & \text { before }\end{array}$ & $1.0^{\mathrm{a}}$ & $2^{\mathrm{a}}$ & $0.75^{\mathrm{a}}$ & $1.5^{\mathrm{a}}$ & $1.75^{\mathrm{a}}$ & $3.5^{\mathrm{a}}$ & $0.9^{\mathrm{a}}$ & $1.8^{\mathrm{a}}$ \\
\hline & $\begin{array}{l}\text { At the same } \\
\text { time }\end{array}$ & $0.98^{\mathrm{a}}$ & $1.95^{\mathrm{a}}$ & $0.74^{\mathrm{a}}$ & $1.48^{\mathrm{a}}$ & $1.72^{\mathrm{a}}$ & $3.43^{\mathrm{a}}$ & $0.89^{\mathrm{a}}$ & $1.78 \mathrm{a}$ \\
\hline & $\begin{array}{l}\text { One week } \\
\text { after }\end{array}$ & $0.96^{\mathrm{a}}$ & $1.92^{\mathrm{a}}$ & $0.73^{\mathrm{a}}$ & $1.45^{\mathrm{a}}$ & $1.69^{\mathrm{a}}$ & $3.37^{\mathrm{a}}$ & $0.88^{\mathrm{a}}$ & $1.75^{\mathrm{a}}$ \\
\hline \multicolumn{2}{|l|}{ Control } & $0.75^{\mathrm{ab}}$ & $1.5^{\mathrm{a}}$ & $0.5^{\mathrm{bc}}$ & $1.0^{\mathrm{a}}$ & $1.25^{\mathrm{bc}}$ & $2.5^{\mathrm{ab}}$ & $0.6^{\mathrm{b}}$ & $1.2^{\mathrm{ab}}$ \\
\hline \multicolumn{2}{|c|}{ Nematode alone } & $0.6^{\mathrm{b}}$ & $1.2^{\mathrm{a}}$ & $0.48^{\mathrm{c}}$ & $0.95^{\mathrm{a}}$ & $1.08^{\mathrm{c}}$ & $2.15^{\mathrm{b}}$ & $0.5^{\mathrm{b}}$ & $0.99^{\mathrm{b}}$ \\
\hline \multicolumn{2}{|c|}{ LSD at 0.05} & 0.16 & 0.47 & 0.12 & 0.41 & 0.21 & 0.66 & 0.14 & 0.39 \\
\hline
\end{tabular}


Meloidogyne spp. under greenhouse conditions

\section{Antioxidant Enzyme in leaves of tomato plants}

Data in Figure (3) showed that the activity of certain biological processes was enhanced as a result of using bacterial strains which reflected as inducers for the systemic resistance of tomato plants and biocontrol agents on nematode. Peroxidase (POX) and polyphenol oxidase (PPO) were increased by all bacterial strains treatments. Plants treated with different selected bacterial strains exhibited increment in their Peroxidase (POX). The enzymes values were ranged from (0.83 to1.15 $\mu \mathrm{g} / \mathrm{g}$.f wt), the maximum POX activity was induced by B. megaterium $(1.19 \mu \mathrm{g} / \mathrm{g} . \mathrm{f} w \mathrm{t})$ at the same time, followed by $(1.15 \mu \mathrm{g} / \mathrm{g} . \mathrm{f} w \mathrm{t})$ at one week before. The minimum POX activity was induced by A. chroococcum at one week before infected by Meloidogyne spp. it recorded $(0.86 \mu \mathrm{g} / \mathrm{g}$.f wt.). Enzyme activity of POX indicated that B. megaterium the highest between all treatments followed by $P$. fluorescens $>$ A.brasilense $>A$. chroococcum. On the other hand, plants treated with the different selected bacterial strains showed increment in their PPO. The enzymes values were ranged from 0.83 to 1.23 ( $\mu \mathrm{g} / \mathrm{g}$.f wt.). The highest increase in PPO enzymes obtained with $B$. megaterium at the same time as it recorded 1.23 ( $\mu \mathrm{g} / \mathrm{g}$.f wt.), while the minimum PPO recorded $(0.83 \mu \mathrm{g} / \mathrm{g}$.f wt.) with $A$. chroococcum at one week after infected by Meloidogyne spp. The presence of Meloidogyne spp. only led to increase the POX and PPO (0.3 and $0.4 \mu \mathrm{g} / \mathrm{g}$.f wt.), respectively compared to healthy plant as recorded $(0.6 \mu \mathrm{g} / \mathrm{g} . f . w t$. 
(A)

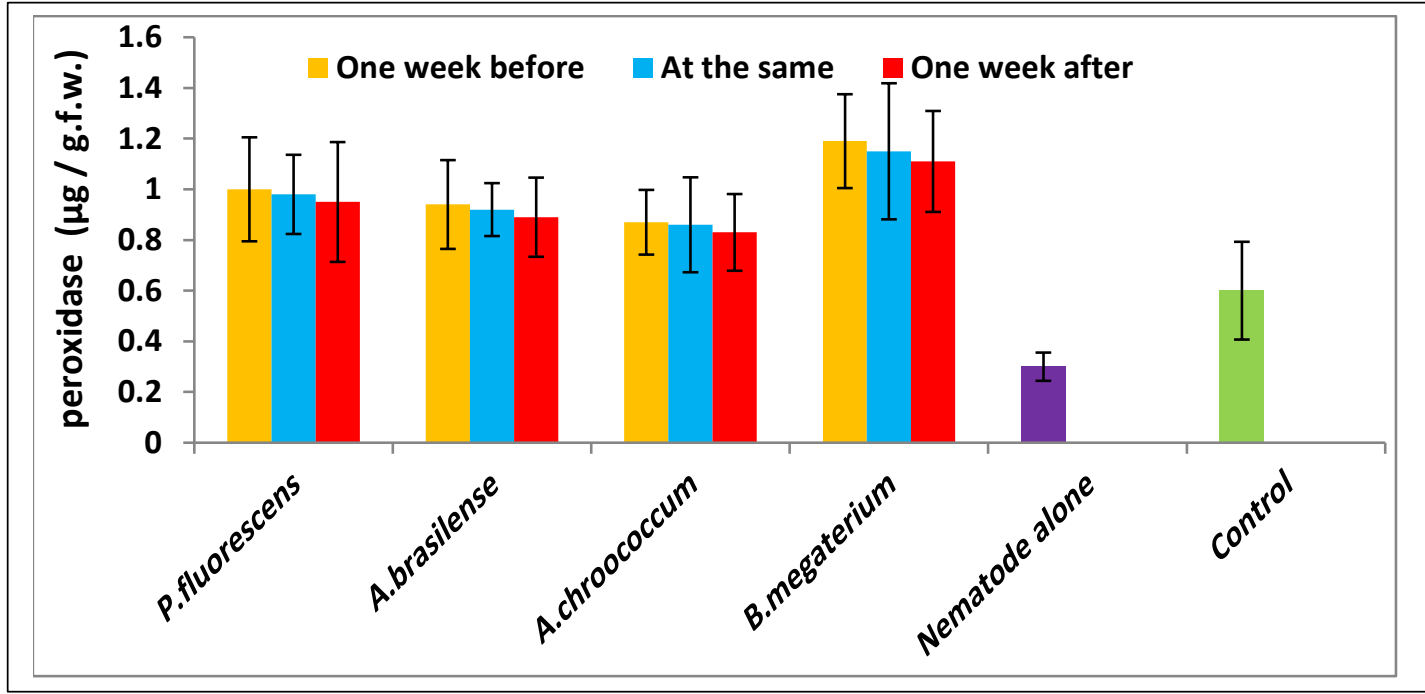

(B)

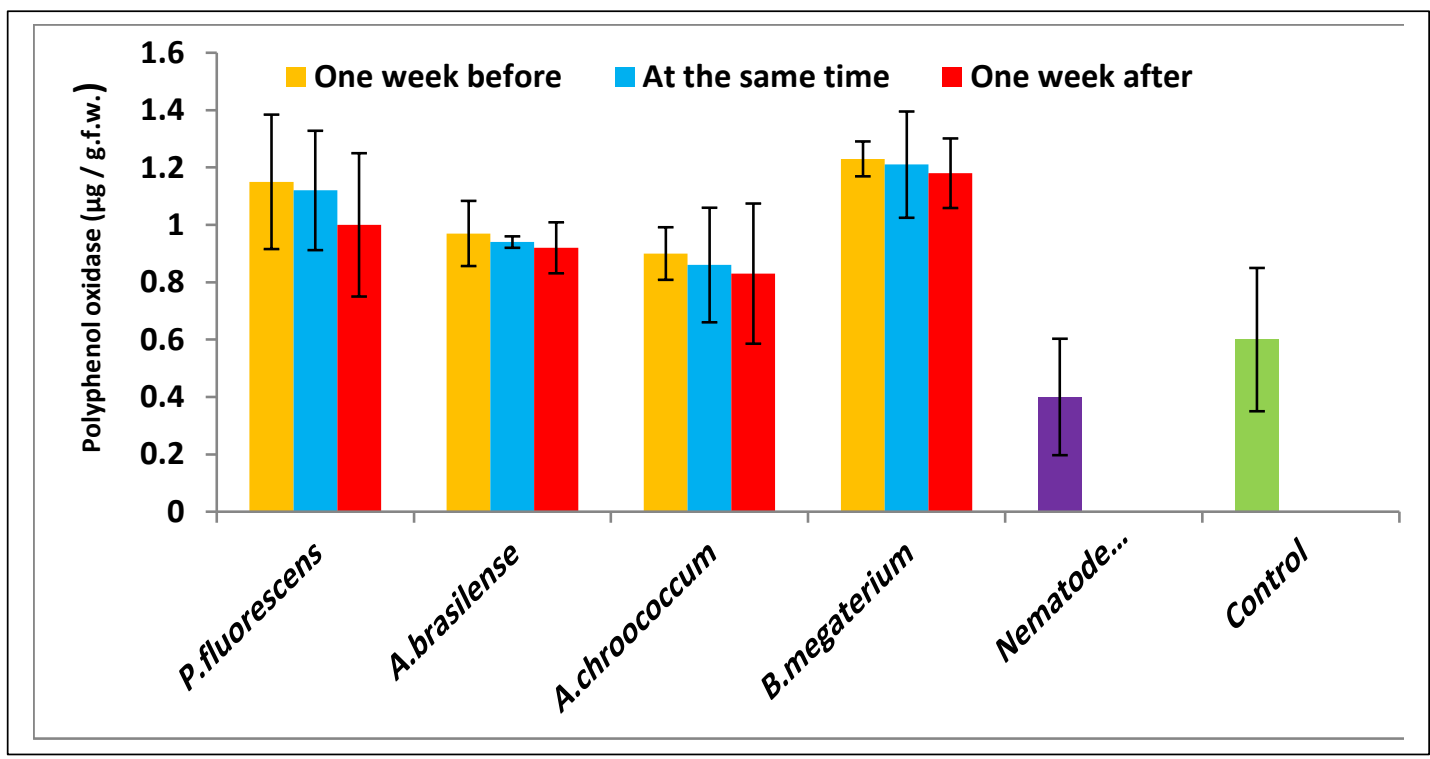

Figure (3): Peroxidase (A) and Polyphenol oxidase (B) in leaves of nematode infected plants inoculated with four liquid bacterial strains at three different application times under greenhouse conditions. Error bars represent the standard deviation between 3 .

\section{Enzymatic Activities and total count of bacteria}

The enzymes activity in rhizospheric area of plants and total count of bacteria are administered by the activity of beneficial microorganisms 
that colonize the plant roots. Data illustrated in Table (4) proved that there was a significantly increase of dehydrogenase activity and total count of bacteria in all different bacterial strains when they applied at all three different application times compared to plants infected with Meloidogyne spp. only. Significant increases in the enzymes activity were attained with the plants inoculated with the microorganisms including; $P$. fluorescens, A. brasilense, A. chroococcum and B. megaterium than uninoculated plants. Applying the bacterial strains at one week before of nematode infected fulfilled the highest enzymatic activity. The enzyme values were ranged from 12 to 21 and 24 to 36 ( $\mu$ g TPF/g soil/day) after 30 and 60 days from transplanting. B. megaterium exhibited the highest enzyme activity of dehydrogenase as recorded 21 and $36 \mu \mathrm{g} \mathrm{TPF} / \mathrm{g}$ soil/day, respectively after 30 and 60 days at one week before nematode inoculation compared to plants treated with nematode alone. Minimum dehydrogenase activity was recorded by $A$. chroococcum applied at one week after nematode inoculation by $12.0 \mu \mathrm{g}$ TPF/g soil/day after 30 days from transplanting.

Also, data illustrated in Table (4) showed an increase in bacterial counts in the rhizosphere region of plants in treatments inoculated with different bacterial than in the rhizosphere region in treatments uninoculated with different bacterial strains. The highest total bacteria count was noted when B. megaterium applied at one week before Meloidogyne spp. inoculation by $25 \times 10^{8} \mathrm{CFU}$ and $51 \times 10^{8} \mathrm{CFU} / \mathrm{g}$ soil after 30 and 60 days from transplanting respectively. Where the lowest bacteria count was noted with A. chroococcum when inoculated at one week after nematode inoculation by $5 \times 10^{8}$ and $26 \times 10^{8} \mathrm{CFU} / \mathrm{g}$ soil, after 30 and 60 days from transplanting respectively compared to other treatments. Additionally, the population of bacteria was increased after 60 days from 
transplanting; on the other hand the total count of bacteria in treated plants with nematode alone recorded lowest bacterial count.

Table (4): Effect of four different bacterial strains at three different applications times on dehydrogenase activity and total count of bacteria of tomato plants infected with Meloidogyne spp. under greenhouse conditions

\begin{tabular}{|c|c|c|c|c|c|}
\hline \multirow[t]{2}{*}{ Bacterial strains } & \multirow[t]{2}{*}{ Applications time } & \multicolumn{2}{|c|}{$\begin{array}{c}\text { Dehydrogenase enzyme } \\
\text { ( } \mu \mathrm{g} \text { TPF/g soil/ day) }\end{array}$} & \multicolumn{2}{|c|}{$\begin{array}{l}\text { Total bacterial counts } \\
\text { ( } \text { x10 }^{8} \mathrm{CFU} \mathrm{g}^{-1} \text { soil ) }\end{array}$} \\
\hline & & 30 days & 60 days & 30 days & 60 days \\
\hline \multirow[b]{3}{*}{ P. fluorescens } & One week before & $18.4^{\text {abcd }}$ & $29.9^{\text {cd }}$ & $19^{\text {bed }}$ & $45^{\text {abc }}$ \\
\hline & " At the same time & $18^{\text {bcde }}$ & $29^{\text {cde }}$ & 1 17 $^{\text {cde }}$ & $\overline{44^{\mathrm{bc}}}$ \\
\hline & One week after & $17.7^{\text {bcde }}$ & $28.4^{\mathrm{de}}$ & $15^{\text {def }}$ & $40^{\text {cd }}$ \\
\hline \multirow[b]{3}{*}{ A.brasilense } & One week before & $1 \mathbf{1 6 . 5}^{\text {cdef }}$ & $27.6^{\mathrm{de}}$ & $14^{\text {def }}$ & $37^{\mathrm{de}}$ \\
\hline & At the same time & $16^{\text {def }}$ & $27.2^{\text {ef }}$ & $\overline{12^{\text {efg }}}$ & $35^{\text {def }}$ \\
\hline & One week after & $15.2^{\text {efg }}$ & $20.8^{\text {ef }}$ & $1 \mathrm{10}^{\mathrm{fgh}}$ & $\mathbf{3 3}^{\text {ef }}$ \\
\hline \multirow[b]{3}{*}{ A. chroococcum } & "One week before & $14.4^{\mathrm{fgh}}$ & $22^{f \mathrm{fg}}$ & 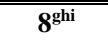 & $31^{\text {efg }^{\text {fg }}}$ \\
\hline & At the same time & $13.2^{\text {ghi }}$ & $24.8^{\mathrm{fg}}$ & $\overline{6}^{h^{\mathrm{hij}}}$ & $29^{\mathrm{fg}}$ \\
\hline & One week after & $12^{\mathrm{hij}}$ & $24^{g}$ & $5^{\text {hij }}$ & $26^{\mathrm{g}}$ \\
\hline \multirow[b]{3}{*}{ B. megaterium } & One week before & $21^{\mathrm{a}}$ & $36^{\mathrm{a}}$ & $25^{\mathrm{a}}$ & $5 \mathbf{5 1}^{\mathrm{a}}$ \\
\hline & At the same time & $20.2^{\mathrm{ab}}$ & $34^{\mathrm{b}}$ & $23^{\text {ab }}$ & $49^{a b}$ \\
\hline & One week after & $19.3^{\mathrm{abc}}$ & $31^{\mathrm{c}}$ & $21^{\text {abc }}$ & $47^{\mathrm{ab}}$ \\
\hline \multicolumn{2}{|c|}{ Control } & $11^{\mathrm{ij}}$ & $18^{\text {h }}$ & $3^{\mathrm{ij}}$ & $5^{5^{h}}$ \\
\hline \multicolumn{2}{|c|}{ Nematode alone } & $11^{\mathrm{j}}$ & $15^{\mathrm{i}}$ & $2^{j}$ & $\mathbf{4}^{\mathrm{h}}$ \\
\hline \multicolumn{2}{|c|}{ LSD at 0.05} & 2.1 & 1.9 & 3.8 & 4.6 \\
\hline
\end{tabular}




\section{DISCUSSION}

Management of plant disease instigated by parasitic organisms has become a challenging mission to the researchers for sustainable agriculture. More than, 4000 parasitic organisms have been recognized and they can be found in most major biomes. Plant parasitic organisms, absorbs the water and nutrient content from their host plants from the vascular tissues (Press and Phoenix, 2005). In this study, we focused on the plant growth promoting rhizobacteria (PGPR) for nematodes biocontrol. Results in (Figure 3 and 4) found that all evaluated rhizobacteria viz, (P .fluorescens, A. brasilense, A. chroococcum and B . megaterium ) significantly reduced Meloidogyne spp. egg hatching and juveniles mortality compared to control. These results also are agreement with those obtained by Huang $\boldsymbol{e t}$ al. (2010) as they revealed that the bacterial culture of B.megaterium YFM3.25 significantly inhibited M.incognita egg hatching and juveniles mortality under in vitro conditions as well as exhibiting a significant reduction in number of galls, egg masses \& eggs /individual egg mass compared to the control under in vivo conditions. This bacterium could decrease nematode parameters because it secreted 17 kinds of nematicidal volatiles such as (benzeneacetaldehyde, 2nonanone, decanal, 2-undecanone \& dimethyl disulphide) which were effective against both of juveniles and eggs at the concentration of 0.5 $\mu$ Mol. Other volatiles viz,( phenyl ethanone, nonane, phenol, 3,5dimethoxy toluene, 2,3-dimethyl-butanedinitrile \& 1-ethenyl-4-methoxybenzene ) which have nematicidal effect at proportion of 30-63\%. Six volatiles i.e. (benzene ethanol, propanone, hexadecane, 2-pentylfuran, propyl -benzene \& 2,6,10 - trimethyl-dodecane )had a low effect against nematode at the rate of $10 \%$. Also Aballay et al. (2013) reported that the inhibition of egg hatching was attributed to the secondary metabolites 
produced by the rhizobacteria which caused egg lysis and affect the egg viability. In order to assist if these plant growth promoting rhizobacteria have a biological control for Meloidogyne spp. on tomato plants, an experimental setups was used including four PGPR viz ( $P$. fluorescens, $A$. brasilense, A. chroococcum \& B. megaterium) against root-knot nematodes under greenhouse condition at three application times (one week before, at the same time and one week after) (Table 1). The time and rate of applications are very significant for the efficacy of bio-control agents. In the present study, repeated applications with one week before showed improved performance than did those applied one week after and at the same time (Khyami-Horani and Al-Banna, 2006). According to Silveira and Freitas (2007), the inoculation of the microorganisms in soil must be as early as possible, as the dynamics of the ecosystem that they challenge to invade may hinder their establishment. Inoculation tomato with different bacterial strains had the potentiality decrease in Meloidogyne spp. parameters i.e. (galls, egg masses, females/root system and $\mathbf{J}_{2}$ in soil) and the reproduction to a huge extent compared to treatments treated with nematode alone (Table 1), Liquid of $P$. fluorescens at one week after nematode infected gave reduction percentages in number of galls, egg masses, and females in root system and $\mathrm{J}_{2}$ in soil. A similar result was reported with those recorded by Oliveira et al. (2009) they confirmed that B.megaterium strains produced secondary metabolites which caused a significant reduction in Meloidogyne exigua reproduction on coffee. Youssef et al. ( 2017) stated that the rhizobacteria that belong to Bacillus i.e. B. subtilis, $B$. megaterium \& B. pumilus showed the nematicidal activity against $M$. incognita in addition to ameliorate the growth parameters of sugar beet also, Sansinenea and Ortiz (2011), indicated that Bacillus spp. produce 
some substances i.e. antimicrobial compounds (antibiotics) such as zwittermicin which produced by B.thuringiensis \& B. cereus not only served which produced by B.thuringiensis \& B. cereus not only served as an antibiotic and antifungal but also had a nematicidal activity. Insunza et al. (2002) stated that plant growth promoting rhizobacteria strains ( P.fluorescens, A.chroococcum \& A.brasilense) inhibited egg hatching and killed juveniles through producing a wide variety of antibiotics, siderorhores, hydrolytic enzymes, organic compounds, HCN, phenol oxidation \& protease. Interestingly, the four different PGPR showed an effect with all growth parameters measured including shoot length, root length, Shoot fresh weight, Root fresh weigh and dry weight of shoot when applied at one week before of nematode infected (Table 2). $P$. fluorescens, A. brasilense, A. chroococcum \& B. megaterium are well known as plant growth promoters (Resende et al., 2004; Fortes et al., 2007). Different microorganisms such as bacteria could be utilized in biological control arena to protect plants against soil borne pathogens. PGPR bacteria are able to colonize the rhizosphere zone and, therefore, can promote plant health against root-knot nematodes (Sikora et al., 2007).Plant growth-promoting bacteria could improve plant growth and nutrition, therefore increasing plant resistance against pathogens (Compant et al, 2005 and Liu et al., 2012). Our Results also are agreement with those obtained by Kalinovskaya et al. (2002); \& Tian $e t$ al. (2007), they reported that the suppression mechanism of root-knot nematode created by microorganisms is through parasitism, competition for colonization of sites and nutrients or production of antibiotics such as lipopeptides and surfactin as well as other enzymes and toxins. All crops treated with B. cereus S18 combined with $M$. incognita showed plant growth improvement when compared with the bacteria untreated crops 
Mahdy (2002);(Burkett-Cadena et al., 2008). Under greenhouse conditions the plant treated with rhizobacterial strains showed enhanced in photosynthetic pigments comparison to control plants (Table 3) these results are aligned with those reported by (Abd-El-Khair et al. 2019). They determined that Bacillus subtilis, B. pumilus and P. fluorescens reduced the $M$. incognita spread in the roots of cow pea and improved the levels of photosynthetic pigments. Generally, the four rhizobacterial strains positively impacted ch.a, chl.b, total chlorophyll and carotenoids in tomato plants after 60 days from sowing. PGPR significantly influence the chlorophyll content (Akhtar et al., 2013; Abo-Koura et al., 2016). The increasing of chlorophyll in all treatments of PGPR probably resulted in higher photosynthetic rates and thus, improved plants biomass (Vafadar et al., 2013). Also, inoculation with bacterial strains significantly increased the carotenoids contents compared to control (Saharan and Nehra, 2011; Metwally et al 2019). Another study conducted by Da Silva et al. (2019) showed that Pinus pinaster infested with nematode infection when inoculated with diazotropic bacteria prevented the degradation of plant pigments and improved their synthesis that in turn up regulated the different metabolic activities of the plants photosynthetic activities observed in the present study might be a result of PGPR up regulating the enzymes related with photosynthetic pigments in plants during nematode attack. The similar reduction in the levels of pigments like chlorophyll, carotenoid in plants infected by nematode was revealed earlier by (Vasil'eva, $\boldsymbol{e t}$ al., 2003) where This decline in plant pigments is primarily because of the inhibition of crucial enzymes required in the Violoxanthin pathway, this in turn impairs the stability of the photosynthetic pathway. The data obtained strongly indicate that PGPR has a great potential as a biological product to enhance antioxidant 
activity in shoots of tomato plants (Figure 3).Commonly related with wounds is necessary to activations of biological defense mechanism. Increase in polyphenol phenol oxidase (PPO) and peroxidase activity (POX) appears to be result of an adaptive response which provides the plant with defense against biotic and abiotic stress (Guida et al., 1992).The protective activity of $P P O$, and peroxidase (POX) was enhanced in susceptible but decreased in resistant plants (Zacheo et al., 1993). Peroxidase avoids the deleterious effect of $\mathrm{O}_{2}^{-}$radicals in root cells and transforms it to $\mathrm{H}_{2} \mathrm{O}_{2}$ which is then transformed by catalase to harmless $\mathrm{O}_{2}+\mathrm{H}_{2} \mathrm{O}$. Therefore, in susceptible tomato roots infested with M. incognita APX activity considerably increased in comparison to uninfected controls and decreased in resistant cultivars (Zacheo et al., 1987). These findings are in harmony with our results whereas, catalase (CAT) increased after nematode infection. This effective role of the total phenols (Figure 3) was studied since 1959 where Clark et al., related the mechanism of disease resistance to the phenolic compounds. They added that this activity because of the quinic acid or caffeic acid parts of chlorogenic acid which are released by the achievement of hydrolytic enzymes such as esterase's. Also, certain phenolic compounds like acetylenes, terpenoid aldehydes, sesquiterpenoids and phenoxypropionic acid derivatives are known to have nematicidal activity (Veech, 1979; Mori et al., 1982; Hayashi et al., 1983).

Enzyme activities could be considered effective indicators of soil quality variations resulting from environmental stress or management practices. Results proved that there was a significantly increase of dehydrogenase activity in all different bacterial strains and total count of bacteria (Table 4). Enzyme activity in soil results from the activity of accumulated enzymes and from enzymatic activity of proliferating 
microorganisms (Kumar et al., 2016). Dehydrogenase activity is considered as display of an overall biological activity in the soil (Benitez et al., 2006; Moeskops et al., 2010). In line with our expectation, dehydrogenase activity was reduced significantly in treatments infected with nematode only. Reduction in dehydrogenase activity indicates the death or depression of the microbial biomass in the soil most likely as a result of the indirect effect of irradiation. It has also found that measurement of changes in soil enzyme activities may provide a beneficial index of changes in soil quality (Visser and Parkinson 1992).In previous experiments, a significant positive correlation was found between total bacterial count and dehydrogenase activity(Buchan et al., 2013; Gebremikael et al., 2014b), plant roots release wide diversity of compounds such as amino acids, organic acids, oligosaccharides, sugar, vitamins, nucleotides, flavonoids, enzymes, hormones, volatile compounds, phenolics, mucilage, carbohydrates and various secondary metabolites, which are increase biological activities in rhizospheric area (Rohrbacher and St-Arnaud, 2016).

\section{CONCLUSION}

The current study illustrates the importance of PGPR in vitro conditions for egg hatching inhibition and larvae mortality of Meloidogyne spp and their evaluation in controlled conditions in a tomato pots trial. Traits PGPR could prove effective on management of Meloidogyne spp, enhancing the growth in the stimulation of plant root system and significant increase in biochemical constitutions and plant defenses. Further studies are needed using new species of PGPR to improve the potentials of bio-agents and succeed safe and ecofriendly management of root-knot nematodes under greenhouse and field conditions. 


\section{REFERENCES}

Aballay, E. ; Ordenes, P. ; Martensson, A. and Persson, P.(2013): Effects of rhizobacteria on parasitism by Meloidogyne ethiopica on grapevines.Eur.J.Plant Pathol.,135:137-145.

Abd-Elgawad, M. M. M. and Aboul-Eid, H.Z. (2001). Effects of oxamyi, insect nematodes and Serratia marcescens on apolyspecific nematode community and yield of tomato. Egyptian Journal of Agronematology, 5: 79-89.

Abd-El-Khair, H. ; El-Nagdi, Wafaa M. A. ; Youssef , M.M.A. ; AbdElgawad, M.M.M. and Dawood, Mona G. (2019). Protective effect of Bacillus subtilis, B. pumilus, and Pseudomonas fluorescens isolates against root knot nematode Meloidogyne incognita on cowpea. Bulletin of the National Research Centre, 43 (64): 1-7.

Abdelmoneim, T. S. (2006). Using some microorganisms or their products for control of plant parasitic nematodes. PhD. Thesis, Faculty of Agriculture, Suez Canal University, Ismailia, Egypt ,1-111.

Abo- Koura, Hanaa A. ; Mahdy, M.E. and Galaall, Neveen M. (2016) .Effect of Immobilized PGPRs Bacteria in Different Forms against RootKnot Nematodes on Tomato Plants .Nature and Science, 14(8) : 129-141.

Akhtar, A.; Abbasi ,H. and Sharf, R. (2013). Study on black gram (Vigna mungo L.) infected with Meloidogyne incognita under the influence of Pseudomonas fluorescens, Bacillus subtilis and Urea . J. Plant Pathol. and Microbiol., 4(9):1-6. DOI: 10.4172/21577471.1000202.

Arnon, D. I. (1949). Copper enzymes in isolated chloroplasts. Polyphenoloxidase in Beta vulgaris. Plant Physiology, 24 (1) : 1-16.

Baldacci-Cresp, F. ; Chang, C. ; Macourt, M. ; Deborde, C. ; Hopkins, J.; Lecomte, P. ; Bernillon, S. ; Brouquisse, R. ; Moing, A. ; Abad, P. ; Herouart, D. ; Puppo, A. ; Favery, B. and Frendo, P. (2012). (Homo) glutathione deficiency impairs root-knot nematode development in Medicago truncatula. PLoS Pathogen/www. Plospathogen. Org. 8(1):e1002471. 
Benitez, E.; Nogales, R.; Campos, M. and Ruano, F. (2006). Biochemical variability of olive-orchard soils under different management systems. Applied Soil Ecology, 32 (2): 221-231.

Braesch , S. (1954). Colorimetric determination of phenoloxidase. Bull. Soc. Chim. Biol., 36 (4-5) : 711-713.

Buchan, D.; Gebremikael, M.T.; Ameloot, Nele ; Sleutel, S. and De Neve, S. (2013). The effect of free-living nematodes on nitrogen mineralization in undisturbed and disturbed soil cores. Soil Biology and Biochemistry, 60: 142-155.

Burkett-Cadena, Marleny ; Kokalis-Burelle, Nancy ; Lawrence, K.S. ; Santen, E.V. and Kloepper, J.W. (2008). Suppressiveness of root-knot nematodes mediated by rhizobacteria. Biological Control, 47 (1) : 55-59.

Chance, B. and Maehly, A.C. (1955). Assay of catalase and peroxidases. Methodes in Enzymol., 2 : 764-775.

Clark, R.S. ; Kuc, J. ; Henze, R.E. and Quacenbush, F.W. .(1959).The nature and fungitoxicity of an amino acid addition product of chlorogenic acid. Phytopathology, (49): 594-598.

Compant, S. ; Duffy, B. ; Nowak, J. ; Clément, C. and Barka, E.A. (2005). Use of plant growth promoting bacteria for biocontrol of plant diseases: principles, mechanisms of action, and future prospects. Appl. Environ. Microbiol., 71(9):4951-4959.

Da Silva, Marta N. ; Pintado, M.E. ; Sarmento, B. ; Stamford, N.P. and Vasconcelos, Marta W. (2019) . A biofertilizer with diazotrophic bacteria and a filamentous fungus increases Pinus pinaster tolerance to the pinewood nematode (Bursaphelenchus xylophilus). Biological Control, 132:72-80.

Daykin, M.E. and Hussey, R.S. (1985). Staining and histopathological techniques in nematology. In : Barker, K.R. ; C.C. Carter and J.N. Sasser (eds), An advanced treatise on Meloidogyne, Vo. II Methodology, pp. 39-48. North Carolina State University Graphics, Raleigh. 
Difco Manual, (1985). Dehydrated culture media and reagents for microbiology . Laboratories incorporated Detroit. Michigan, 48232 USA. $\mathrm{P}:$ 1027and 621 .

Duncan, D. B. (1955). Multiple range and multiple F tests. Biometrics, 11: $1-42$.

Fortes, F. D-O. ; Da Silva, A.C.F.; Almança, M. A. K. and Tedesco, S. B. (2007). Root induction from microcutting of an Eucalyptus sp. clone by Trichoderma spp. R. Árvore, Viçosa-MG, 31(2): 221-228, DOI: 10.1590/S0100-67622007000200004.

Gebremikael, M.T.; Buchan, D. and De Neve, S. (2014). Quantifying the influences of free-living nematodes on soil nitrogen and microbial biomass dynamics in bare and planted microcosms. Soil Biology and Biochemistry, 70: 131-141.

Gugino, B. ; Ludwig, J. and Abawi, G. (2008). An on-farm bioassay for assessing Meloidogyne hapla infestations as decision management tool. Crop Protection, 27 : 785-791.

Guida, G. ; Zacheo, G . and Bleve-Zacheo ,T. (1992). Activation of detoxifying enzymes in tomato roots following paraquat treatment and nematode infection. Nematol. Medit., 20 (2) :203-209.

Hayashi, M.; K. Wada and K. Munakata. (1983). Synthesis and nematicidal activity of phenoxypropionic acid derivatives. Agric. Biol. Chem., (47): 2653-2655.

Hortencia, G.M. ; Olalde, V. and Violante, P. (2007). Alteration of tomato fruit quality by root inoculation with plant growth promoting rhizobacteria (PGPR) : Bacillus subtilis BEB-13bs. Sci. Hortic., 113 : 103-106.

Huang, Y. ; Xu, C. ; Ma, L. ; Zhang, K. ; Duan,C. and Mo, M. (2010). Characterization of volatiles produced from Bacillus megaterium YFM3.25 and their nematicidal activity against Meloidogyne incognita. Eur .J. Plant Pathol., 126 (3) : 417-422. 
Hussey, R. S. and Barker, K. R. (1973). A comparison of methods collecting inocula of Meloidogyne spp. including a new technique . Plant Disease Reporter, 57 : 1025-1028.

Insunza, V. ; Alstrom, Sadhna and Eriksson, K. B. (2002). Root bacteria from nematicidal plants and their biocontrol potential against trichodorid nematodes in potato. Plant and Soil, 241 (2) : 271-278.

Kalinovskaya, Natalie I. ; Kuznetsova, Tatyana A. ; Ivanova, Elena P. ; Romanenko, Lyudmila A. ; Voinov, V.G. ; Huth, F. and Laatsch, H. (2002). Characterization of surfactin-like cyclic depsipeptides synthesized by Bacillus pumilus from ascidian Halocynthia aurantium. Mar. Biotechnol. , 4 :179-188.

Kerry, B.R. and Hidalgo-Diaz, L. (2004). Application of Pochonia chlamydosporia in the integrated control of root-knot nematodes on organically grown vegetable crops in Cuba. IOBC WPRS Bull., 27 : 23 26.

Khyami-Horani, Hala and Al-Banna, Luma. ( 2006). Efficacy of Bacillus thuringiensis jordanica against Meloidogyne javanica infecting tomato. Phytopathol. Mediterr., 45 (2) : 153-157.

Kiewnick, S. and Sikora, R. (2005). Biological control of the root-knot nematode Meloidogyne incognita by Paecilomyces lilacinus strain 251. Biological Control, 38 : 179-187.

Kumar, A. ; Singh, Vandana ; Singh, Monika ; Singh, P.P.; Singh, S.K.; Singh, P.K. and Pandey, K. D. (2016). Isolation of plant growth promoting rhizobacteria and their impact on growth and curcumin content in Curcuma longa L. Biocatal. Agric. Biotechnol., 8: 1 - 7.

Liu, J. ; Luo, J. ; Ye, H . and Zeng, X. (2012). Preparation, antioxidant and antitumor activities in vitro of different derivatives of levan from endophytic bacterium, Paenibacillus polymyxa EJS-3. Food and Chem. Toxicol., 50 (3-4) : 767-772.

Mahdy, M.E. (2002). Biological control of plant parasitic nematodes with antagonistic bacteria on different host plants. Ph.D. Thesis, Bonn University, Germany, 1-182. 
Metwally, W. E. ; Khalil , A. E. and Mostafa, Fatma A.M. (2019). Biopesticides as eco-friendly alternatives for the management of rootknot nematode, Meloidogyne incognita on cowpea ( Vigna unguiculata L.). Egypt. J. Agronematol., 18 (2) : 129-145.

Mhatre, P.H. ; Karthik, C. ; Kadirvelu, K. ; Divya, K.L. ; Venkatasalam, E. P. ; Srinivasan, S. ; Ramkumar, G. ; Saranya , C. and Shanmuganathan, R. (2019). Plant growth promoting rhizobacteria (PGPR): a potential alternative tool for nematodes bio-control. Biocatalysis and Agricultural Biotechnology, 17 (3) : 119-128.

Moeskops, B. ; Sukristiyonubowo ; Buchan, D.; Sleutel, S.; Herawaty, Lenita ; Husen, E.; Saraswati, R.; Setyorini, D. and De Neve, S.( 2010). Soil microbial communities and activities under intensive organic and conventional vegetable farming in West Java, Indonesia. Applied Soil Ecology, 45 (2) : 112-120.

Mori, M.; Be-Hyeon, S. ; Kimura, Y. and Suzuki, A. (1982). The nematicidal activity of acetylene compounds. Agric. Biol. Chem., 46 (1) : 309-311.

Oliveira, D. F. ; Carvalho, H. W. P. ; Nunes, A. S. ; Campos, V. ; Silva, G. H. and Campos, V. A. C. (2009). Active substances against Meloidogyne exigua produced in a liquid medium by Bacillus megaterium. Nematologia Brasileira , 33 : 271-277.

Press, M.C. and Phoenix, G.K. (2005). Impacts of parasitic plants on natural communities. New Phytol., 166 (3) : 737-751.

Resende, Maria D-L. ; De Oliveira, J. A. ; Guimaraes, R. M. ; Pinho, R.G.V. and Vieira, A.R. (2004). Inoculação de sementes de milho utilizando o Trichoderma harzianum como promotor de crescimento. Ciênc. agrotec., 28 (4): 793-798.

Rohrbacher, F. and St-Arnaud , M. (2016). Root exudation: the ecological driver of hydrocarbon rhizoremediation. Agronomy ,6 (1) : 1 27. 
Saharan, B. S. and Nehra,V. (2011). Plant Growth Promoting Rhizobacteria : a Critical review. Life Sciences and Medicine Research, Volume 21:1- 30.

Sansinenea, Estibaliz and Ortiz, Aurelio. (2011). Secondary metabolites of soil Bacillus spp. Biotechnol. Lett., 33 : 1523-1538.

Siddiqui, I. A. and Shaukat, S. S. (2002). Mixtures of plant disease suppressive bacteria enhance biological control of multiple tomato pathogens. Biology and Fertility of Soils, 36 (4) : 260-268.

Sikora, R. A. ; Schafer, K. and Dababat, A. A. (2007). Modes of action associated with microbially induced in planta suppression of plant parasitic nematodes. Australasian Plant Pathology, 36 (2) : 124-134.

Silveira, A. P. D. and Freitas, S. D. S. (2007). Microbiota do solo e qualidade ambiental. Campinas: Instituto Agronômico ,317p.

Teymouri, M. ; Ebrahimipour, G. ; Karkhane, M. and Marzban, A. (2016). Metal resistant and phosphate solubilizing bacterium improves maize (Zea mays) growth and mitigates metal accumulation in plant. Biocatal. Agric. Biotechnol., 8 : 13-17.

Thalman , A. (1967). Uber die microbiello a ktiviatat undihr benziehung $\mathrm{zu}$ frucht bartkeits merkmalen einger a charboden unter besonderer beruksi chtigung der Dehydrogenase aktiviatal (TTC. Reduktion). Biss, Gieben. Ph. D. Thesis, W. Germany. that target nematodes. Proc. Natl. Acad .Sci .USA., $100:$ 2760-2765.

Tian, B. ; Yang , J. and Zhang, K-Q. (2007). Bacteria used in the biological control of plant parasitic nematodes : populations, mechanisms of action and future prospects. FEMS. Microbiol. Ecol. , 61 (2) : 197-213.

Vafadar, Farinaz ; Amooaghaie, R. and Otroshy, M. (2013). Effects of plant growth-promoting rhizobacteria and arbuscular mycorrhizal fungus on plant growth, stevioside, NPK, and chlorophyll content of Stevia rebaudiana. J. Plant Interactions, 9 (1):128-136.

Vasil'eva, I . S. ; Vanyushkin, S . A. ; Zinov'eva, S . V. ; Udalova, Z.V. ; Bolychevtseva, I. V. and Paseshnichenko, V. A. (2003). 
Photosynthetic pigments of tomato plants under conditions of biotic stress and effects of furostanol glycosides. Applied Biochemistry and Microbiology , 39 (6) : 689-696.

Veech, J.A. (1979). Histochemical localization and nematoxicity of terpenoid aldehydes in cotton. J. Nematol., 11 (3) : 240-246.

Vincent, J. M. (1970). A manual for the practical study of the rootnodule bacteria. International Biological Programme by Blackwell Scientific , (15) : 164.

Visser, Suzanne and Parkinson, D. (1992). Soil biological criteria as indicators of soil quality: soil microorganisms. American Journal of Alternative Agriculture, 7 (1-2) : 33 - 37.

Youssef, M. M. A. ; Abd-El-Khair, H. and El-Nagdi, Wafaa M. A-E. (2017). Management of root-knot nematode, Meloidogyne incognita infecting sugar beet as affected by certain bacterial and fungal suspensions. Agric. Eng. Int. : CIGR Journal, 19 (5) : 293-301.

Zacheo ,G . ; Orlando, Chistina and Beleve-Zacheo, Teresa. (1993). Characterization of anionic peroxidases in tomato isolines infected by Meloidogyne incognita. J. Nematol. , 25(2) : 249-256.

Zacheo, G. ; Bleve-Zacheo, Teresa and Pricolo, G. (1987). Metabolic changes in enzyme levels in potato roots infested by potato cyst nematodes, Globodera pallida (Pa3) and Globodera rostochiensis (Ro1). Nematol. Medit., 15 : 293-302. 